\title{
Modelling of solar thermal energy for household use in equatorial latitude by using the F-Chart model
}

\author{
Mateo Astudillo-Flores ${ }^{1}$, Esteban Zalamea-Leon ${ }^{2}$, Antonio Barragán-Escandón ${ }^{3}$ M.R.Pelaez- \\ Samaniego ${ }^{4}$, John Calle-Siguencia ${ }^{5}$. \\ ${ }^{1}$ Dirección de Investigación de la Universidad de Cuenca \\ Phone/Fax number: +593978780009, e-mail: mateo.astudillof@ucuenca.edu.ec \\ ${ }^{2}$ Faculty of Architecture, Univesidad de Cuenca, Cuenca-Ecuador \\ ${ }^{3}$ Energy Research Group, Universidad Politécnica Salesiana, Cuenca - Ecuador \\ ${ }^{4}$ Faculty of Chemical Sciences, Universidad de Cuenca, Cuenca-Ecuador \\ ${ }^{5}$ Energy Research Group, Universidad Politécnica Salesiana, Cuenca- Ecuador \\ e-mail: mateo.astudillof@ucuenca.edu.ec, esteban.zalamea@ucuenca.edu.ec
}

\begin{abstract}
The Andean Equatorial Region, due to its geographic location, shows great potential for using solar energy. Solar thermal energy is of interest in the residential sector in Ecuador and other Andean countries as a method to avoid fossilderived fuels consumption. However, previous learnings of the operation of solar water heating systems in other latitudes cannot be used in the conditions of Ecuador. Thus, the performance of the solar thermal energy systems in this geographic region deserves further study that consider typical high levels of cloudiness and fast climate oscillations. The objective of this work was to investigate the effect of the orientation of solar thermal plates on their energy efficiency and model the behaviour of these systems to predict their operation under Equatorial Andean climate conditions. For the F-Chart calibration different slopes angles were used, according to the typical roofs slopes in Cuenca, Ecuador. Results showed a monthly solar fraction, contributed by an evacuated tube collector is $26 \%$ higher than the flat plate collectors. The results also depict that, in the conditions of Cuenca, the greater solar water heating occurs when the collector is inclined $14^{\circ}$ and facing towards the south. These findings can be used to predict the best operational conditions for using solar thermal energy collectors to produce hot water in the residential sector under equatorial highland altitude conditions.
\end{abstract}

Key words. Solar Energy, Andean Cities, Flat Plate Collector, Evacuated Tube Collector.

\section{Introduction}

Global economic growth is responsible for constant increase on energy consumption [1]. Among the energy sources that are used to supply such energy demand, solar is becoming widely used for both power production and heating requirements. Solar energy is by far the source with the greatest potential among renewable energy sources [2]. One of the most common and efficient ways for taking advantage of the solar is for domestic hot water (DHW) production [3], [4]. In Europe, since the nineties it has existed a strong commitment to use of solar thermal technologies (ST) at large scale, especially in the household sector [5], [6]. Conversely, Latin America still uses fossil fuels, especially petroleum liquid gas (LPG) as the main energy source, representing around $26 \%$ of the energy matrix of the region [7]-[9]. In Ecuador, the State's spending on LPG subsides in 2019 was 764.4 million dollars [10], which represented approximately $20 \%$ of the State's budget for education in the same year. The resources spent on LPG and other imported fuels (e.g., diesel) are onerous to the country. Currently, Ecuador imports more than $70 \%$ of the LPG which is used mostly in the residential sector for cooking and water heating (no heating demands are in Ecuador). Moreover, despite of LPG being a "clean fuel" in comparison to other hydrocarbon fuels, it's still a net $\mathrm{CO}_{2}$ emitter. Furthermore, Ecuador's LPG distribution system is very inefficient (i.e., it uses land transport, which also burns subsidized diesel) and dangerous. The ST technology is a promising clean alternative for residential water heating in the country and the required equipment can be locally manufactured [11], generating local employment and, at the same time, avoiding LPG use.

The Andean equatorial zone offers a high potential for the implementation of ST technologies. This part of the planet is a privileged place due to high solar radiation rates that can be used for thermal applications [12] and photovoltaic electricity production [13], [14]. In this region there is a constant weather condition, and direct and diffuse solar radiation as well through the year, they also have a growing demand for energy, and thermal requirements have notably increased [15]-[17]. Nevertheless, the potential of ST traditional technologies is hindered by the cloudiness variability and temperature changes throughout the day. Such particular weather conditions in Andean highlands has not been considered in previous studies and models that could be used for predicting the potential of this type of energy in the region. This correlates to a reduction of pollutants and climate change [18]. Determining the energy capacity of different solar technologies is essential to know the real local capability 
[19], [20]. A ST system allows to turn the solar radiation into thermal energy.

In a solar water heating system (SWHS) the solar collector is the most important component that acts as a heat exchanger, takes the solar irradiation temperature and transmit the captured irradiation to the circulating fluid [19]. Therefore, the correct selection of the technology is important when installing SWHS, this depends on the heat restrictions and the environmental conditions of a place [1], [19], [21]. Furthermore, an ideal condition is that it can be deployed in edifications and urban areas [22] because, unlike photovoltaic electricity, the transfer of the heat generated, just like its long storage, implies major energy losses. The ST technologies most commercially used for the production of DHW are evacuated tube collectors (ETC) and flat plate collectors (FPC) [1], [3], [19].

The FPCs are usually constituted by a flat glazed cover that allows access of solar irradiation to an absorption plate, configuring a solar box, which is usually dark colour to improve energy capture [21]. The plate transfers the captured energy to ducts in circulation conducts, which also transmit to a fluid that circulates through the ST collector. The solar box that boosts the heat through the greenhouse effect is magnified through layers of insulation that reduce losses by convection effect to the external air. The glazed surface which covers the collector, also allows the greenhouse effect between the covered surface and the absorption plate, thus reducing radiation losses [3], [23]. In the ETCs, a long plate with a heat tube exchanger is inside a vacuum sealed glass tube. As there is low amounts of air inside the tube or air in stationary state, which allows convection losses to be very low, which means higher efficiency in cold climates[12], [24], [25]. Given the occurrence of climate oscillation in the region, temperatures vary from cold to moderately warm, thus causing high and constant levels of both direct and diffuse radiation. In regions with climate oscillation between moderated hot and cold in fast-changing proportions of direct and diffuse irradiation it is important to compare these two technological possibilities for a better selection. One of the easiest ways is by determining the contributed solar fraction.

Nowadays, there are some methods and tools that are more or less precise and allow estimating for the solar thermal performance of solar heating systems. These tools are based on static or dynamic simulations that seek to determine the solar fraction or contribution to specific energy requirements [26].Using the parameters of the proportion of usable energy, compared to the total amount of captured radiation, we can calibrate a universal method among the available tools. The F-Chart method is widely used around the world as it allows for a fast and relatively easy way to estimate the long-term thermal performance expected in ST collectors. Besides, it is widely used for the design of active and passive heating systems and, particularly, for the evaluation of the ST collector's performance [27]. Once the tool has been validated, ST storage can be planned with optimized storage [28]. This method is easily programmable in spreadsheets. In countries such as Chile this tool is freely distributed through the Ministry of Energy [29].
Nevertheless, it's important to emphasize that the method that uses the information (e.g., solar radiation, temperature of water and air network, thermal demand and solar incidence) must be locally analysed.

The objective of this study is to determine both ETCs and FPCs efficiency, and the solar fraction for thermal demand of a family by the F-Chart method calibration, taking in account different orientations and a slope that reflects the typical roofs in a city located in the Andean Equatorial Region, Cuenca - Ecuador.

\section{Materials and Methods}

This study focuses on the calibration of the F-Chart method in the Andean city of Cuenca - Ecuador, which presents a quasi-stationary climate, whose average ambient temperature is around $15{ }^{\circ} \mathrm{C}$ [30], [31] and it is located at latitude and longitude $\left(-2.901691{ }^{\circ} \mathrm{S}\right.$, $79.010151^{\circ} \mathrm{E}$ ) with an altitude of 2560 m.a.s.l. For the FChart calibration, different degrees of inclination of typical roofs of the city were taken into account $\left(14^{\circ}\right.$, $18.26^{\circ}, 26.56^{\circ}$ and $45^{\circ}$ ) [13] in order to deploy the solar plates in parallel to the roof' surface to reduce architectural impact [32]. Therefore, it is necessary that there is methodical integration of different variables, including: incident solar radiation, environmental temperature, local water temperature and the thermal demand of a typical family of four.

Local solar radiation and site temperature measurements were collected during the year 2019 by the Weather Station, Delta-T WS-GP2 model (United Kingdom) [33], with a time step frequency of 10 minutes. The temperature of the potable water network was also measured with the help of solar systems controllers (Solar Electronics SR658) [34]. The information was stored and processed following recommendations of the World Meteorological Organization (WMO) [35] and it was complemented by the available radiation quantification and the energy supplied calculation.

The raw global incident solar radiation data on a horizontal surface obtained by the meteorological station was processed by means of correlated equations, which allows determining the solar resource in a specific area [36], [37]. With the Cooper equation (1), the declination $(\delta)$ was obtained. Then, with equation (2), the hourly angle of sunset $\left(\omega_{\mathrm{s}}\right)$ was calculated, which depends on the declination and the latitude $(\varphi)$. Later, using equation (3) and the solar constant (Ics $=1367 \mathrm{~W} / \mathrm{m}^{2}$ ) the extraterrestrial radiation on a horizontal surface $\left(\mathrm{H}_{\mathrm{e}}\right)$ in this geographic location is determined.

$$
\begin{gathered}
\delta=23.45 \sin \left(360 \frac{284+n}{365}\right) \\
\omega_{s}=\arccos (-\tan (\varphi) \tan (\delta)) \\
H e=\frac{24}{\pi} I_{c s} \times A \times B(3) \\
A=\left(1+0.034 \cos \cos \left(\frac{360 n}{365}\right)\right)
\end{gathered}
$$




$$
B=\left(\cos (\varphi) \cos (\delta) \sin \left(\omega_{s}\right)+\frac{\pi \omega_{s}}{180} \sin (\varphi) \cos (\delta)\right)
$$

For the calculation of the monthly average value of terrestrial solar radiation on a sloped surface $\left(\mathrm{H}_{t}\right)$, the equation (6) was used [4], [37] which relates the direct radiation $\left(\mathrm{H}_{\mathrm{b}}\right)$, the diffuse radiation $\left(\mathrm{H}_{\mathrm{d}}\right)$, the value of the monthly average radiation measured with the meteorological station $\left(\mathrm{H}_{\mathrm{o}}\right)$ which allows to establish the diffuse and direct radiation proportion and the daily direct radiation coefficient on a sloped surface. Then the monthly average value of the direct radiation on the ground $\left(\mathrm{R}_{\mathrm{b}}\right)$ could be calculated with equation (7) [3]. Moreover, given the difficulty of calculating $\mathrm{H}_{\mathrm{d}}$, the Liu - Jordan correlation was used (8), (9) to determine this parameter.

$$
\begin{gathered}
H t=H b R b+\frac{1+\cos (\beta)}{2} H d+\rho \frac{1-\cos (\beta)}{2} H o \\
R b=\frac{\cos (\varphi-\beta) \cos (\delta) \sin \left(\omega_{s}^{\prime}\right)+\left(\frac{\pi}{180}\right) \omega_{s}^{\prime} \sin (\varphi-\beta) \sin (\delta)}{\cos (\varphi) \cos (\delta) \sin \left(\omega_{s}\right)+\left(\frac{\pi}{180}\right) \omega_{s} \sin (\varphi-\beta) \sin (\delta)} \\
\frac{H d}{H o}=1.39-4.02 K T+5.531 K T^{2}-3.108 K T^{3} \\
K T=\frac{H o}{H e}
\end{gathered}
$$

The DHW demand of a single family made up of four people is shown in Table I [38], [39]. The monthly average of the necessary thermal load to cover DHW needs at $60{ }^{\circ} \mathrm{C}$ of temperature of a typical family was figured out using equation (10) [39].

Table I DHW demand of a family made up of four people in

\begin{tabular}{|l|l|l|l|l|}
\hline Activity & Cuenca - Ecuador [38]. \\
\hline Shower & $07: 00$ & $14: 00$ & $20: 00$ & $\begin{array}{c}\text { Total (per } \\
\text { activity) }\end{array}$ \\
\hline Sink & $52 \mathrm{~L}$ & - & $52 \mathrm{~L}$ & $104 \mathrm{~L}$ \\
\hline Kitchen Sink & $20 \mathrm{~L}$ & $16 \mathrm{~L}$ & $20 \mathrm{~L}$ & $56 \mathrm{~L}$ \\
\hline Total (per hour) & $80 \mathrm{~L}$ & $16 \mathrm{~L}$ & $16 \mathrm{~L}$ & $40 \mathrm{~L}$ \\
\hline
\end{tabular}

$$
D_{A C S}=V_{A C S} \times \rho_{a} \times C_{p} \times\left(T_{r e q}-T_{r e d}\right) \times N
$$

Where $\mathrm{D}_{\mathrm{ACS}}$ is the DHW demand $(\mathrm{kWh}), \mathrm{V}_{\mathrm{ACS}}$ is the DHW storage volume $(\mathrm{L}), \rho_{\mathrm{a}}$ represents the water density (1000 $\left.\mathrm{kg} / \mathrm{m}^{3}\right), \mathrm{Cp}$ is the water's specific heat $\left(4187 \mathrm{~J} / \mathrm{kg}^{\circ} \mathrm{C}\right)$, and $\mathrm{T}_{\text {req }}$ and $\mathrm{T}_{\text {red }}$ represents the required hot water temperature $\left({ }^{\circ} \mathrm{C}\right)$ and the water network temperature $\left({ }^{\circ} \mathrm{C}\right)$, respectively. The thermal load was calculated considering an increase of $10 \%$ to compensate storage losses. The F-Chart method is based on equation (11). The proportion (fraction) of solar energy provided by solar thermal system is given by the $f$ factor [27].

$$
f=1.029 X-0.065 Y-0.245 X^{2}+0.0018 Y^{2}+0.0215 X^{3}
$$

$$
\begin{aligned}
& X=\frac{\text { Collector's Abosorbed Energy }_{\text {Monthly Thermal Energy Demand }}}{Y}=\frac{\text { Collector's Lost Energy }}{\text { Monthly Thermal Energy Demand }}
\end{aligned}
$$

The thermal energy captured by the collector (CAE) is given by equation (14).

$$
C A E=F_{R}(\tau \alpha)_{n} \times \frac{F_{R}{ }^{\prime}}{F_{R}} \times \frac{(\tau \alpha)}{(\tau \alpha)_{n}} \times H t \times N \times A c
$$

Where $F_{R}(\tau \alpha)_{n}$ is the collector optical efficiency; that is, the ordinate at the origin of the characteristic curve. $F_{R}{ }^{\prime} / F_{R}$ is the correction factor of the collector-exchanger assembly $(0.96) .(\tau \alpha) /(\tau \alpha)_{\mathrm{n}}$ is the angle of incidence modifier; in this case, it was used the one suggested by the collector's technical test; $\mathrm{N}$ is the number of days of de month and $\mathrm{A}_{\mathrm{c}}$ is the collector area $\left(\mathrm{m}^{2}\right)$.

Also, the energy losses in the collector (CEL) is given by the equation (15).

$$
C E L=F_{R} U_{L} \times \frac{F_{R^{\prime}}}{F_{R}}(100-T a) \times \Delta t \times A c \times k 1 \times k 2 \times k 3
$$

Where, $F_{R} U_{L}$ corresponds to the characteristic performance curve of the collector, determined under laboratory condition. $\mathrm{k} 1$ is the storage corrector factor (16), this factor can be used if the condition presented in equation (17) is satisfied. $\mathrm{k} 2$ is the correction factor that can be calculated with equation (18), this factor relates the minimum DHW temperature of the water from the network and the monthly average environment temperature. Finally, k3 is the slope and azimuth correction factor calculated with equations (19) and (20).

$$
\begin{gathered}
k 1=\left(\frac{k g \text { of acumlation }}{75 \times A c}\right)^{-0.25} \\
37.5<\frac{k g \text { of acumulation }}{m^{2} \text { de colector }}<300 \\
k 2=11.6+1.18 T_{\text {req }}+3.86 T_{\text {red }}-\frac{2.32 T a}{100-T a} \\
k 3=1-\left(1.2 \times 10^{-4}\left(\beta-\beta_{\text {opt }}\right)^{2}+3.5 \times 10^{-5} \vartheta^{2}\right) \\
\text { para } 15^{\circ}<\beta<90^{\circ} \\
k 3=1-\left(1.2 \times 10^{-4}\left(\beta-\beta_{\text {opt }}\right)^{2}\right) \\
\text { para } \beta<15^{\circ}
\end{gathered}
$$

Where $\beta$ is the actual inclination of the collector and $\beta_{\text {opt }}$ is the collector optimums slope, which corresponds to an inclination equal to the latitude [37], [40]. $\vartheta$ is the orientation of the collector in which its performance is analysed.

For this study case the characteristic curves given by the standardized tests of STC were use both for the FPC and 
the ETC. Table II shows the obtained values for $\mathrm{F}_{\mathrm{R}}(\tau \alpha)_{\mathrm{n}}$ and $\mathrm{F}_{\mathrm{R}} \mathrm{U}_{\mathrm{L}}$.

Table II. Solar Collectors characteristics.

\begin{tabular}{|c|c|c|}
\hline Collector & $\mathbf{F}_{\mathbf{R}} \mathbf{U}_{\mathbf{L}}\left(\mathbf{W} / \mathbf{m}_{\mathbf{2}}{ }^{\circ} \mathbf{C}\right)$ & $\mathbf{F}_{\mathbf{R}}(\boldsymbol{\tau} \boldsymbol{\alpha}) \mathbf{n}(\mathbf{\%})$ \\
\hline FPC & 5.5 & 0.6675 \\
\hline ETC & 1.35 & 0.46 \\
\hline
\end{tabular}

Finally, the annual solar fraction (F) presented in equation (21) is the sum of the product of the monthly solar fraction by the monthly load, divided by sum of the the monthly load.

$$
F=\frac{\sum_{i=1}^{12} f i L i}{\sum_{i=1}^{12} L i}
$$

\section{Results and Discussion}

The average global solar radiation expected in the city of Cuenca during the year is relatively constant throughout the year, with a small variation compared to other latitudes. The trend changes during June and July, in which there is a decrease of $38 \%$ in comparison to September, which presents the highest radiation. Moreover, for both June and July, in Cuenca there is an increase on thermal demand by $\sim 6 \%$ in comparison to other months. Table III shows the data used for the parameterization of the F-Chart model.

Table III. Data used for parameterization of the F-Chart model

\begin{tabular}{||ccccc||}
\hline Month * & $H_{t}\left(\frac{\mathrm{kWh}}{\mathrm{m}^{2}} \times\right.$ mes $)$ & $T_{\text {red }}\left({ }^{\circ} \mathrm{C}\right)$ & $T_{a}\left({ }^{\circ} \mathrm{C}\right)$ & $L(k W h)$ \\
\hline January & 4.081 & 13.43 & 15.43 & 299.544 \\
February & 3.910 & 13.92 & 15.92 & 267.366 \\
March & 4.121 & 13.89 & 15.89 & 296.229 \\
April & 4.320 & 12.88 & 14.88 & 293.716 \\
May & 4.192 & 12.21 & 14.21 & 308.335 \\
June & 3.072 & 11.59 & 13.59 & 302.712 \\
July & 3.599 & 11.70 & 13.70 & 312.010 \\
August & 4.318 & 11.60 & 13.60 & 312.730 \\
September & 4.984 & 12.57 & 12.57 & 295.878 \\
October & 4.677 & 12.46 & 14.46 & 306.533 \\
November & 4.509 & 13.19 & 15.19 & 291.555 \\
December & 4.196 & 13.73 & 15.73 & 297.382 \\
\hline
\end{tabular}

*average monthly solar radiation, network temperature and air temperature measured with weather station; thermal demand calculated for a family made up of four people in the city of Cuenca - Ecuador.

The analysis of the data shows that the solar fraction of the ETC decreases as tilt angle increase (Fig. 1), thus, this type of collector presents the highest solar contribution at a $14^{\circ}$ slope and oriented towards south. This effect is repeated in the FPC, in which a similar behavior is observed (Fig. 2). It's important to mention that angles less than $14^{\circ}$ were not taken into consideration due to the typical slopes of the city's roofs.
Also, the annual solar fraction of both technologies for the different orientations and slopes is presented below (Table IV).

Table IV. Annual solar fraction measured for the orientations and inclinations proposed

\begin{tabular}{|c|c|c|c|}
\hline Inclination & Orientation & $F-E T C$ & $F-F P C$ \\
\hline $14^{\circ}$ & \multirow{4}{*}{ South } & 0.405 & 0.341 \\
\hline $18^{\circ}$ & & 0.397 & 0.283 \\
\hline $26^{\circ}$ & & 0.376 & 0.263 \\
\hline $45^{\circ}$ & & 0.299 & 0.194 \\
\hline $14^{\circ}$ & \multirow{4}{*}{ North } & 0.405 & 0.341 \\
\hline $18^{\circ}$ & & 0.342 & 0.333 \\
\hline $26^{\circ}$ & & 0.321 & 0.313 \\
\hline $45^{\circ}$ & & 0.244 & 0.243 \\
\hline $14^{\circ}$ & \multirow{4}{*}{ East/West } & 0.405 & 0.341 \\
\hline $18^{\circ}$ & & 0.279 & 0.225 \\
\hline $26^{\circ}$ & & 0.258 & 0.206 \\
\hline $45^{\circ}$ & & 0.181 & 0.137 \\
\hline
\end{tabular}

The monthly solar fraction contributed by the ETC is $26 \%$ higher than FPC. The solar contribution for both technologies drastically decreases by $\sim 39 \%$ during June, July and August (Fig. 3).

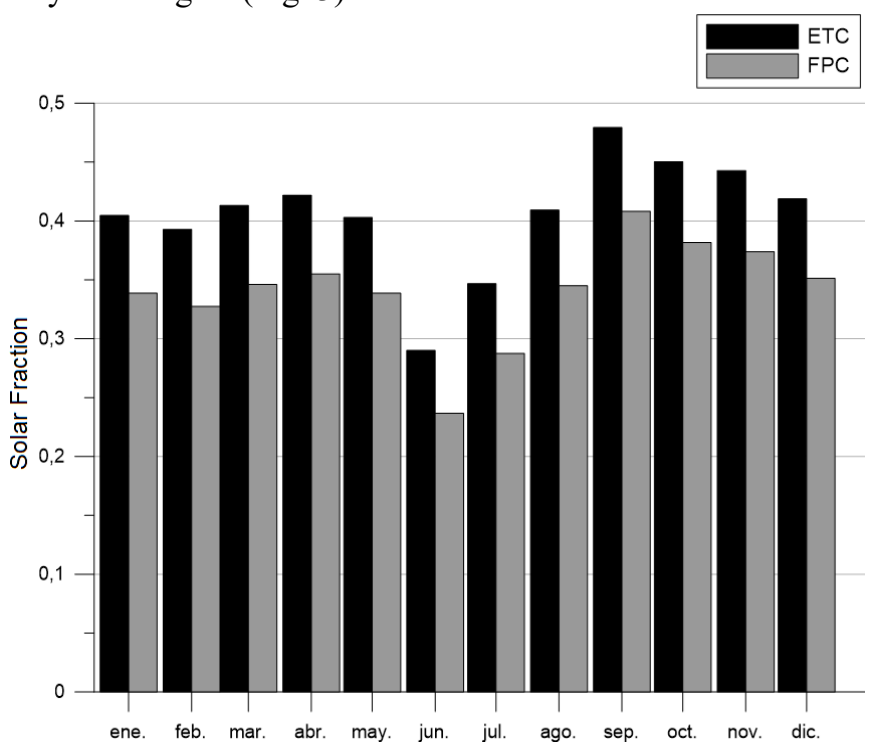

Fig. 3. Monthly solar fraction contributed - FPC vs ETC

The application of the F-Chart model shows that the highest yearly solar contribution Cuenca occurs when a collector is oriented towards the South, which is part a consequence of the less cloudiness when the solar path is over the southern hemisphere (summer months in the southern hemisphere). These results are not in line with expected results based on the city's location (2,9 South). Due to geographic location, the highest solar energy production in the city in months June to August, in normal conditions, should occur when the plates are oriented towards the North. The opposing results are the 


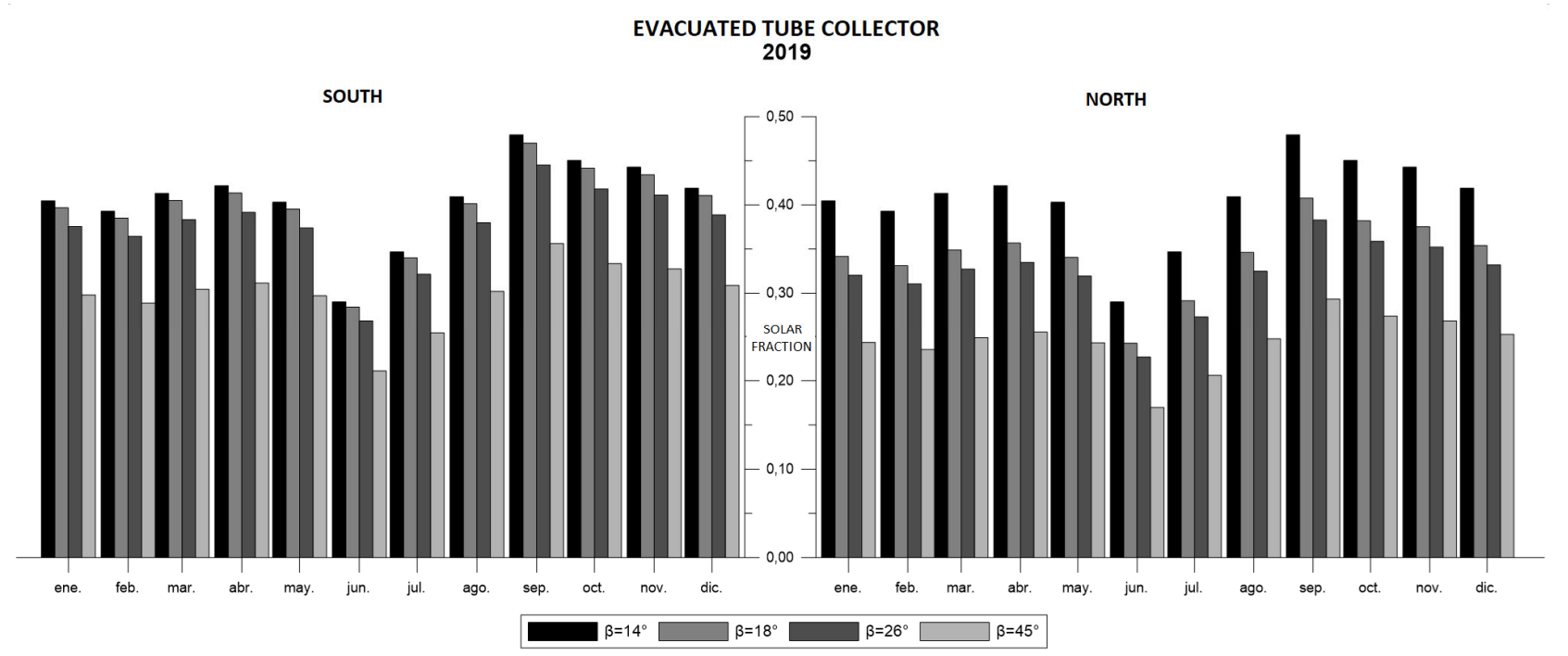

Fig. 1. Solar thermal fraction in the city of Cuenca - Ecuador according to ETC with typical roofs slopes

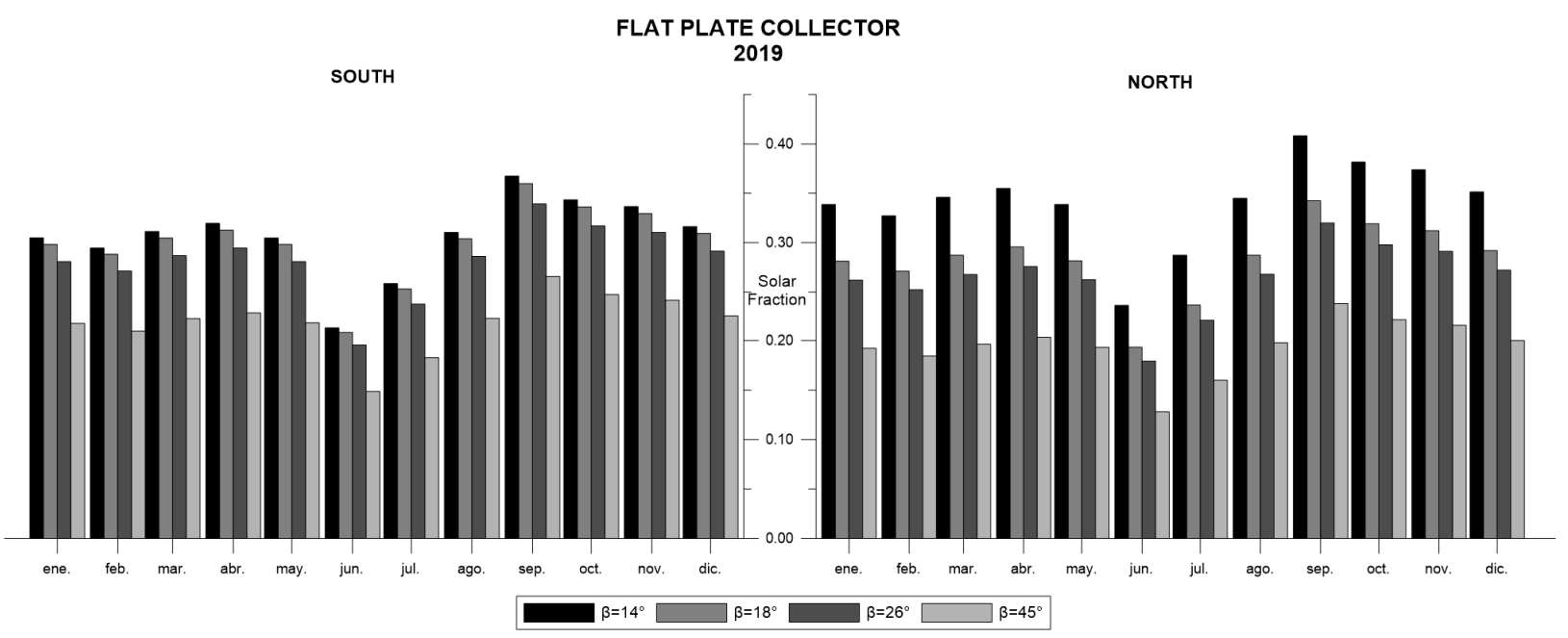

Fig. 1. Solar thermal fraction in the city of Cuenca - Ecuador according to FPC with typical roofs slopes

consequence of high cloudiness in the region in the referred months. In addition, as expected, the ETC has a higher solar fraction compared to the FPC.

There is no significant variation in the solar fraction when the collector is arranged at an inclination of $14^{\circ}$ regardless of orientation, as indicated by Méndez and Cuervo [37]. This is because the F-Chart model does not have a correction factor that includes the azimuth when the collector is located with an inclination less than $15^{\circ}$ towering any location. Moreover, for this geographic location and despite the fact that the thermal demand is almost constant through the year, it is not recommended to use the optimal inclination of the collector (equal to the latitude), because it does not adjust to the typical local roof arrangements. The ST products also need some inclination for the internal thermosiphoning effect of the refrigerant, and also because the roofs' slopes favour natural rain cleaning. Also, it is confirmed that in the equatorial zone, if the tilt angle decreases, the harnessed energy that is converted into heat increases and, therefore, higher water temperatures are achieved [12]. This may be due to the incidence area of solar radiation increase therefore captured energy increase.
The model also shows that the solar fraction increases if the collector area does, the number of collectors, and also when the requirement of water temperature decreases [12]. However, the number of the collectors could be increased if the required water temperature increases, this to compensate the missing solar fraction.

Although this model was calibrated for a required water temperature of $45^{\circ} \mathrm{C}$ but it can be used for other conditions, as long as it does not exceed $60^{\circ} \mathrm{C}$, which is the limit to avoid the risk for hot water users in a conventional residential requirements. In addition, it shouldn't be calibrated either with a temperature less than $40^{\circ} \mathrm{C}$ due to human comfort conditions.

In climate locations such as Turkey (Latitude between 36 ${ }^{\circ}$ and $42^{\circ} \mathrm{N}$ ) and Chile (Latitude between $35^{\circ}$ and $71^{\circ}$ $\mathrm{S})$, where the contributed solar fraction in months of higher irradiation levels (summer and spring) for ETC and FPC technologies reach a solar typical residential fraction up to $70 \%$ and $55 \%$ (Turkey), and $66 \%$ and $37 \%$ (Chile) [41], [42]. But in winter, for both technologies the supply proportion reaches a $35 \%$ solar fraction for ETC and $23 \%$ for FPC. In contrast, in the Andean equatorial zone with quasi-stationary climates, the solar fraction is close to $47 \%$ 
and $40 \%$ for the ETC and FPC respectively. Therefore, it is not as high as expected as consequence of the cloudiness effect.

The number of required collectors will decrease between $22,22 \%$ and $38.58 \%$ if ETC technology replacing FPCs. It is important to mention that the model allows predicting the solar fraction that a collector located in a specific place with a certain inclination and orientation may cover, which in this specific case will be according to the typical roofs of the city, considering climatic and geographical conditions. This allows the design of SWHS with greater efficiency.

\section{Conclusion}

This work aimed at determining the performance and the solar fraction of ST collectors of type FPC and ETC in Andean equatorial climates by applying the F-Chart method. The results confirm that, as expected, the performance of the ETC is superior to FPC, which is affected by the local cold air and cloudiness in these geographic regions. The work also identified that, for both solar collector types, both the yield and the solar fraction increase as the collector is closer to the horizontal position. The results of F-Chart modelling shows that the orientation in which a collector is located is not as important as long as the slope is close to horizontal disposition, but taking account the thermosiphon effect and cleanliness. However, in this geographic location when the inclination is higher than mentioned, the largest solar fraction is theoretically verified when the collector is oriented towards the south, but with a low difference respect to another orientations The results of this work provide useful information for future evaluations of the use of ST technologies as a viable alternative for the production of domestic hot water in regions with quasi-stationary climates, such as that in the equatorial region. More research and experimentations could help to confirm this ST technology performance in Andean equatorial climates.

\section{Acknowledgement}

This research was supported by Dirección de Investigación de la Universidad de Cuenca, DIUC. It is part of the "Calibración de modelo F-Chart para colectores solares térmicos con parametrización y validación acorde a disposiciones típicas para integración arquitectónica en climas ecuatoriales andinos" .The authors also appreciate the support of the Energy Research Group (GIE) of the Universidad Politécnica Salesiana.

\section{References}

[1] L. Evangelisti, R. De Lieto Vollaro, and F. Asdrubali, "Latest advances on solar thermal collectors: A comprehensive review," Renew. Sustain. Energy Rev., vol. 114, no. March, p. 109318, 2019, doi:

10.1016/j.rser.2019.109318.

[2] R. Perez and M. Perez, "A Fundamental Look At Energy Reserves For The Planet," Int. Energy Agency SHC Program. Sol. Updat., vol. 50, no. April, pp. 4-6, 2009, [Online]. Available: http://www.ieashc.org/data/sites/1/publications/2015-11-A-
Fundamental-Look-at-Supply-Side-Energy-Reservesfor-the-Planet.pdf.

[3] S. a. Kalogirou, "Solar thermal collectors and applications," Prog. Energy Combust. Sci., vol. 30, pp. 231-295, 2004, doi: 10.1016/j.pecs.2004.02.001.

[4] J. A. Duffie and W. A. Beckman, Solar Engineering of Thermal Processes, Edición: 4. Hoboken: Wiley, 2013.

[5] M. Szabo, "The Potential of Solar Thermal in Europe," in Green Buildings and Renewable Energy: Med Green Forum 2019 - Part of World Renewable Energy Congress and Network, A. Sayigh, Ed. Cham: Springer International Publishing, 2020, pp. 491-497.

[6] W. Weiss and P. Biermayr, "Potential of Solar Thermal in Europe," Vienna, 2009.

[7] A. Asociación Regional de Empresas del sector Petróleo Gas y Biocombustibles en Latinoamérica y el Caribe, "Tendencias del Sector Gas Natural en América Latina y el Caribe.," Jul. 2016.

[8] A. Mesa, C. Giusso, and D. M. Galvez, "The Preservation of the Solar Potential in Cities of Hispanic Trace. Analysis of the Current Situation, and Future Potential in Urban Areas of Argentina," Energy Procedia, vol. 57, pp. 3071-3080, 2014, doi: 10.1016/j.egypro.2015.06.053.

[9] A. Asociación Colombiana del GLP, "Informe del Sector del GLP," Jul. 2019.

[10] Centro de investigaciones economicas ESPOL, "Boletin de politica economica Nro 6," Guayaquil, 2020. [Online]. Available:

https://www.finanzas.gob.ec/wp-

content/uploads/downloads/2019/07/Presentación_BID BPE-1.pdf.

[11] J. Alvarez, "Paneles Solares Térmicos JA," 2018 http://www.juanalvarez.com.ec/paneles-solarestermicos/ (accessed May 18, 2018).

[12] C. Recalde, C. Cisneros, C. Avila, W. Logroño, and M. Recalde, "Single Phase Natural Circulation Flow through Solar Evacuated Tubes Collectors on the Equatorial Zone," Energy Procedia, vol. 75, pp. 467472, 2015, doi: 10.1016/j.egypro.2015.07.424.

[13] I. F. Izquierdo Torres, M. G. Pacheco-Portilla, L. G. Gonzalez-Morales, and E. F. Zalamea-León, "Simulación fotovoltaica considerando parámetros de integración en edificaciones," Ingenius, no. 21, pp. 2131, Apr. 2018, doi: 10.17163/ings.n21.2019.02.

[14] A. Barragán-Escandón, J. Terrados-Cepeda, E. Zalamea-León, and P. Arias-Reyes, "Electricity production using renewable resources in urban centres," Proc. Inst. Civ. Eng. - Energy, vol. 171, no. 1, pp. 12-25, Feb. 2018, doi: 10.1680/jener.17.00003.

[15] B. Trewin, "The climates of the Tropics, and how they are changing," James Cook Univ., p. 13, 2014.

[16] A. Bykerk - Kauffman, "Seasons and Why the Equator is Warmer than the Poles," Pedagogy in Action. Jul. 2018.

[17] I. R. E. Agency, "Global Atlas for Renewable Energy,” Jul. 2015.

[18] J. Rigter, D. Saygin, and G. Kieffer, "Renewable Energy in Cities," Int. Renew. Energy Agency, p. 64, 2016.

[19] A. Jamar, Z. a. A. Majid, W. H. Azmi, M. Norhafana, and A. A. Razak, "A review of water heating system for solar energy applications," Int. Commun. Heat Mass Transf., vol. 76, pp. 178-187, Jul. 2016, doi: 10.1016/j.icheatmasstransfer.2016.05.028.

[20] E. Zalamea-León and F. Quesada, "Criterios de integración de energía solar activa en arquitectura. Potencial tecnológico y consideraciones proyectuales," Rev. Arquit., vol. 19, no. 1, pp. 56-69, Jun. 2017, doi: 10.14718/revarq.2017.19.1.1018. 
[21] Y. Tian and C. Y. Zhao, "A review of solar collectors and thermal energy storage in solar thermal applications," Appl. Energy, vol. 104, pp. 538-553, Jul. 2013, doi: 10.1016/j.apenergy.2012.11.051.

[22] A. Barragán-Escandón, J. Terrados-Cepeda, and E. Zalamea-León, "The Role of Renewable Energy in the Promotion of Circular Urban Metabolism," Sustainability, vol. 9, no. 12, p. 2341, 2017, doi: 10.3390/su9122341.

[23] M. Khoukhi and S. Maruyama, "Theoretical approach of a flat-plate solar collector taking into account the absorption and emission within glass cover layer," Sol. Energy, vol. 80, no. 7, pp. 787-794, Aug. 2006, doi: 10.1016/j.solener.2005.06.002.

[24] A. Shafieian, M. Khiadani, and A. Nosrati, "Thermal performance of an evacuated tube heat pipe solar water heating system in cold season," Appl. Therm. Eng., vol. 149, pp. 644-657, Jul. 20019, doi:

10.1016/j.applthermaleng.2018.12.078.

[25] E. Zambolin and D. Del Col, "Experimental analysis of thermal performance of flat plate and evacuated tube solar collectors in stationary standard and daily conditions," Sol. Energy, vol. 84, no. 8, pp. 1382-1396, 2010, doi: 10.1016/j.solener.2010.04.020.

[26] M. de Guadalfajara, "Método simple para el cálculo de sistemas solares térmicos centralizados con acumulación estacional," Jul. 2020.

[27] F. Obaco and J. Jaramillo, "Sistemas solar-térmicos : algoritmo operativo para aplicar el método F- Chart en la evaluación de colectores solares," pp. 1-3, 2010.

[28] J. S. Haberl and S. Cho, "Literature Review of Uncertainty of Analysis Methods (F-Chart Program), Report to the Texas Commission on Environmental Quality,” Jul. 2004.

[29] Ministerio de Energía Gobierno de Chile, “¿Qué son los Sistemas Solares Térmicos?," Ministerio de Energía. Jul. 2015.

[30] A. Edelman et al., "State of the Tropics," James Cook University, Cairns, Jun. 2014.

[31] M. Baquero and F. Quesada, "Eficiencia energética en el sector residencial de la Ciudad de Cuenca, Ecuador," Maskana, vol. 7, no. 2, pp. 147-165, 2016, doi: 10.18537/mskn.07.02.11.

[32] M. C. Munari Probst and C. Roecker, "Architectural Integration Quality," in Architectural Integration and Design of Solar Thermal Systems, EPFL PRESS., Italia, 2011, pp. 27-29.

[33] "Delta-T Devices - Registro de datos, humedad del suelo, meteorología y botánica. Resumen de Productos.," 2016.

[34] "Operation Manual of Solar Controller SR658 for Split Solar System," 2017.

[35] World Meteorological Organization, Guidelines on Best Practices for Climate Data Rescue, 2016 editi. Geneva: WMO, 2016.

[36] S. A. Kalogirou, "Solar Energy Engineering: Processes and Systems: Second Edition," ResearchGate. Apr. 2020.

[37] J. Méndez Muñíz and R. C. N.-333. 79. 3 Cuervo Garcia, "Energía solar térmica." Madrid, España, p. 522, 2010.

[38] J. Calle, "Integración de sistemas solares térmicos eficientes para obtener agua caliente sanitaria y disminuir la contaminación ambiental en el cantón Cuenca," Repos. Tesis - UNMSM, Jun. 2018.

[39] J. Calle - Sigüencia and O. Tinoco - Gómez, "Obtención de ACS con energía solar en el cantón Cuenca y análisis de la contaminación ambiental," Ingenius, no. 19, pp. 89-101, Apr. 2018, doi: 10.17163/ings.n19.2018.09.

[40] C. de D. Tecnológico, "CDT : Sistemas Solares
Térmicos.” Jun. 2007.

[41] A. Kocer, I. Atmaca, and C. Ertekin, “A COMPARISON OF FLAT PLATE AND EVACUATED TUBE SOLAR COLLECTORS WITH F-CHART METHOD," p. 10.

[42] C. Escobar and J. Tomás, "Diagnóstico del comportamiento de dos sistemas solares térmicos orientados a la generación de agua caliente sanitaria en viviendas sociales mediante el programa de protección al patrimonio familiar: Aplicación en la Región Metropolitana,” Jun. 2018. 